\title{
EFFECT OF CHEMICAL ADMIXTURES ON MECHANICAL PPROPERTIES OF ROLLER COMPACTED CONCRETE
}

\author{
S.Krishna Rao ${ }^{1}$, Y.Mohan Sai Kiran ${ }^{2}$ \\ ${ }^{1}$ Associate Professor, Civil Engineering Department, V.R.Siddhartha Engineering College, Andhra Pradesh, India \\ ${ }^{2}$ M.Tech Student, Civil Engineering Department, V.R.Siddhartha Engineering College, Andhra Pradesh, India
}

\begin{abstract}
This paper presents the experimental work carried out in order to evaluate the mechanical properties of roller compacted concrete mixtures in which a chemical admixture like super plasticizer is added in different dosages. The dosage percentages namely $0.5 \%, 0.75 \%$ and $1 \%$ by weight of cement have been added to RCC. Tests we performed to determine workability when $R C C$ is in fresh state and mechanical properties when RCC is in hardened state. Workability like compaction factor test, vee bee test and slump test were conducted. Strength tests like compression strength, modulus of rupture and split tensile strength at 3 days, 7 days and 28days. Experimental investigation revealed that significant increases in strengths were observed in RCC with increase in super plasticizer dosage addition. Also workability of concrete was increased with increase in SP dosage.
\end{abstract}

Keywords: Roller Compacted Concrete Pavement, Vee Bee Time, Modulus of Rupture, Super Plasticizer

\section{INTRODUCTION}

Roller compacted concrete pavement is a special concrete, compacted by vibratory roller compaction (ACI 207.5R-992004). The methods used to construct roller compacted concrete pavements (RCCP) are very similar to those methods employed in construction of Asphalt pavements constructed in various countries [USACE1995]. Due to the ability of gaining of early flexural strength, minimized construction work and use of no form work have been encouraged many highway engineers to use this special concrete for pavement applications.

The materials of RCCP are very identical to those of pavement quality control (PQC). RCC was suggested as a substitute for conventional hot mix pavement or bituminous concrete pavements under hot climate conditions prevailing in Indian sub continent.

Very little information was available today on the effects of chemical admixtures on the properties of RCCP mixes. Since the volume of cement paste is low; the properties of RCCP may not be similar to those of conventional cement concrete. For instance very little improvement has been found with the usage of super plasticizers in RCCP.

Unreliable evidence exists as the usage of super plasticizers with RCCP mixes, but no specification is available to guide the mix designer to select the appropriate dosage of super plasticizer [Halil Ceylon]

Super plasticizers were used to combat the problems in mixing and placing RCC in transit mixes.

RCC mixes are very low or zero slump concrete mixers that could be very stiff, harsh and difficult to work with. Any increase in workability of RCC mixtures has been noticed with the use of water reducers, but again the effect is not clearly understood.
The objective of this present investigation is to develop the understanding of the effect of super plasticizers on RCC mixtures and to prepare recommendations for their appropriate usage.

Super plasticizers are chemical admixtures added to RCC to obtain specific concrete strength using lower cement content. This result in lower $\mathrm{CO}_{2}$ emissions per volume of concrete produced, so concrete properties were improved and also help in placing the concrete in different and difficult conditions. Recent advancement in admixture technology has helped in the development of middle range water reducers.

The use of various types of chemical admixtures in roller compacted concrete pavement is limited since RCC shows the required mechanical properties; therefore there is a little need to study the workability properties of RCCP. Also the requirements of superplasticizers in RCC are low when compared to other types of concrete [PCA R\&D 3243].

Objectives of the experimental work:

1. To study the workability of RCC.

2. To study the effect of super plasticizer on mechanical properties of RCCP.

\section{MATERIALS}

Materials are chosen on the basis of required flexural strength and pavement usage (ACI 325.10R-99 2004), in this experimental work materials used are coarse and fine aggregates, ordinary Portland cement, water and super plasticizer. 


\subsection{Coarse and Fine Aggregates:}

In the experimental work hard broken granite stones with nominal maximum size of aggregates (NMSA) of $19 \mathrm{~mm}$ were used as coarse aggregates. The gradation test results for coarse and fine aggregates were shown in fig. 1 and fig. 2 .
As per the gradation limits specified in ACI 211.3R.02 were chosen and a composition of 60percent coarse aggregates and 40 percent fine aggregates and conforms to the desirable limits. The combined gradation diagram is shown in fig. 3 .

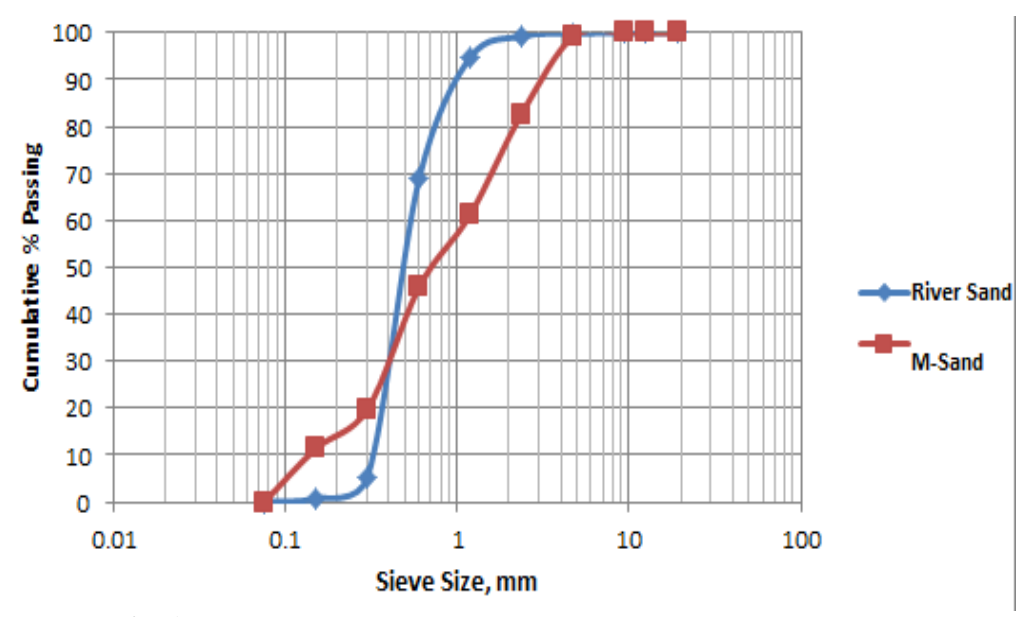

Fig.1 Particle Size Distribution Curve for Fine Aggregate

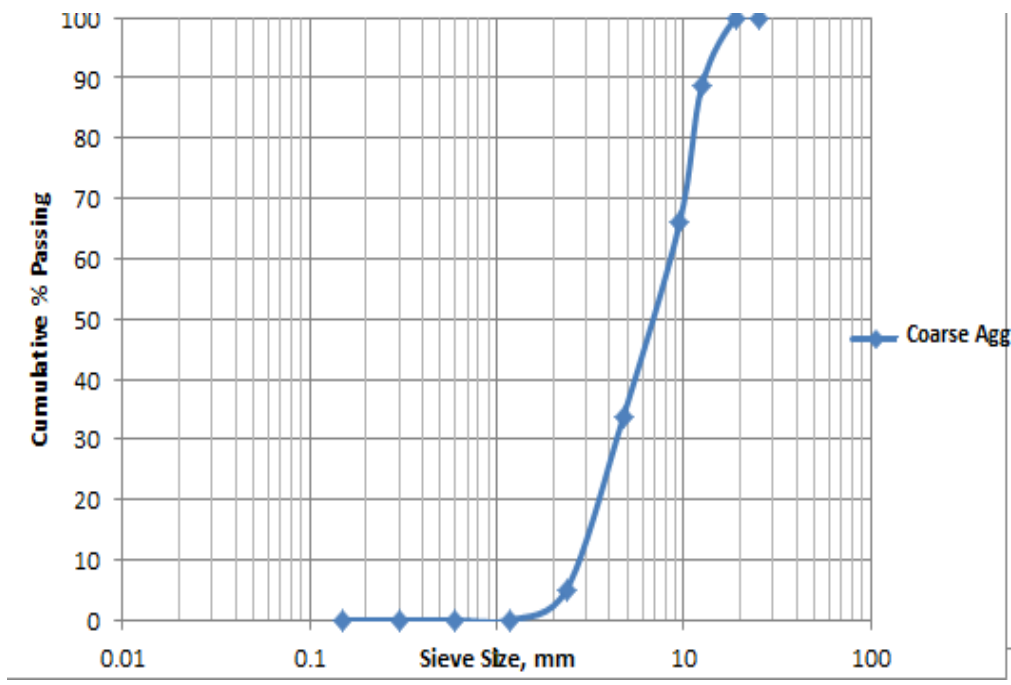

Fig.2 Particle Size Distribution Curve for Coarse Aggregate

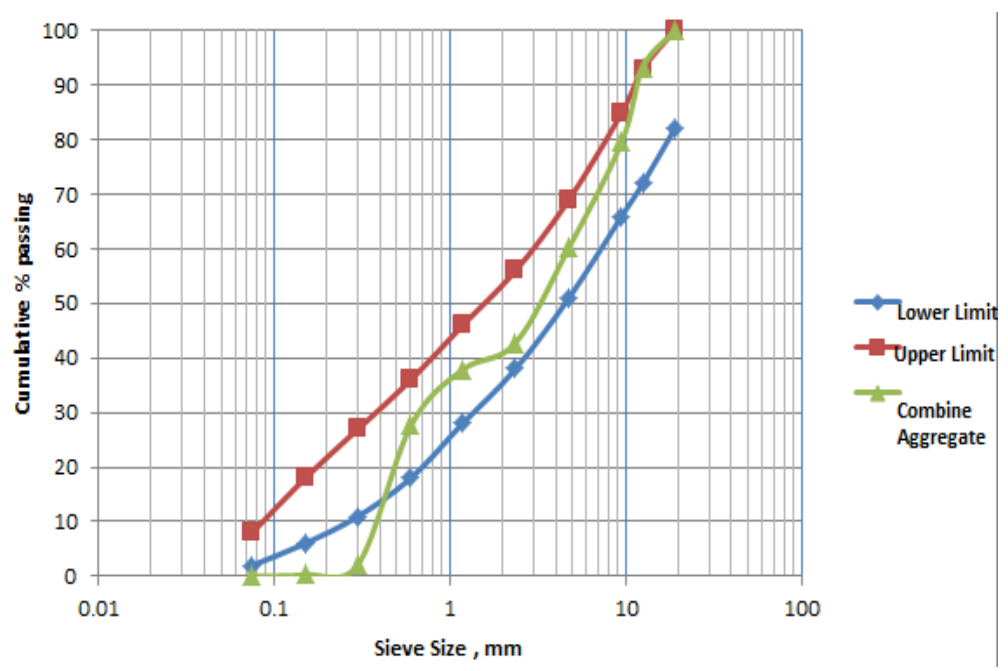

Fig.3 Particle Size Distribution Curve for Combined Aggregate 


\subsection{Cement:}

The cement used in the present work is Ordinary Portland cement (OPC) of 53 grade, conforming to the requirements of IS: 1226 was used. Physical properties of cement were given in table 1. The cement was tested as per IS 4031-1989. The specific gravity of cement was 3.15 .

Table 1: Physical properties of cement

\begin{tabular}{|l|l|l|}
\hline S.NO. & TEST PROPERTY & RESULT \\
\hline 1. & $\begin{array}{l}\text { Fineness } \\
\text { (a) } \quad \text { Sieve test } \\
\text { (b) Blaine }\end{array}$ & $2 \%$ \\
& Normal Consistency & $285 \mathrm{~m}^{2} / \mathrm{kg}$ \\
\hline 2. & Specific Gravity & 3.15 \\
\hline 3. & Initial setting time & $105 \mathrm{minutes}$ \\
\hline 4. & Final setting time & $295 \mathrm{minutes}$ \\
\hline 5. & Compressive strength & \\
\hline 6. & (a) 3days & $32 \mathrm{~N} / \mathrm{mm}^{2}$ \\
& (b) 7days & $41 \mathrm{~N} / \mathrm{mm}^{2}$ \\
& (c) 28days & $59 \mathrm{~N} / \mathrm{mm}^{2}$ \\
\hline
\end{tabular}

\subsection{Chemical Admixtures:}

In this experimental work sulphonated naphthalene based super plasticizer (SP) was used. The SP used for the study conforms to IS 9103-1999

\subsection{Water:}

The water used in RCC mix design was potable and drinking water

\section{MIX PROPORTIONING}

Mix proportioning was done using ACI 211.3R-02-2004 specifications based on soil-compaction method which is a soil based approach. The method was developed for RCC pavements of roads and is limited to mix design with maximum NMSA of $19 \mathrm{~mm}$ (ACI 325.10R-99). The identification of mix proportions and quantity of materials are given in Table2. Table 3 gives the workability of different mixes. The mix was proportioned for specified target of flexural strength of $4.5 \mathrm{Mpa}$.

Table 2: Mix Proportions

\begin{tabular}{|l|l|l|l|l|l|}
\hline Mix & $\begin{array}{l}\text { Cement } \\
\left(\mathrm{kg} / \mathrm{m}^{3}\right)\end{array}$ & $\begin{array}{l}\text { Fine } \\
\text { Aggregat } \\
\mathrm{e}\left(\mathrm{kg} / \mathrm{m}^{3}\right)\end{array}$ & $\begin{array}{l}\text { Coarse } \\
\text { Aggregat } \\
\mathrm{e}\left(\mathrm{kg} / \mathrm{m}^{3}\right)\end{array}$ & $\begin{array}{l}\text { Water } \\
\left(\mathrm{kg} / \mathrm{m}^{3}\right.\end{array}$ & $\begin{array}{l}\text { w/c } \\
\text { rati } \\
\mathrm{o}\end{array}$ \\
\hline $\begin{array}{l}\text { Contr } \\
\text { ol mix }\end{array}$ & 295 & 842 & 1264 & 127 & 0.43 \\
\hline
\end{tabular}

Table 3: RCC Mix Design with SP

\begin{tabular}{|l|l|l|l|l|l|l|l|l|}
\hline Mix & $\begin{array}{l}\text { Ce } \\
\text { me } \\
\text { nt, } \\
\text { kg }\end{array}$ & $\begin{array}{l}\text { Sp } \\
\text { lit }\end{array}$ & $\begin{array}{l}\text { Fa, } \\
\text { kg }\end{array}$ & $\begin{array}{l}\text { Ca, } \\
\text { kg }\end{array}$ & $\begin{array}{l}\text { W, } \\
\text { kg }\end{array}$ & W/c & $\begin{array}{l}\text { C.f } \\
\cdot\end{array}$ & $\begin{array}{l}\text { V- } \\
\text { b,s } \\
\text { ec }\end{array}$ \\
\hline RCC1 & 295 & 1.47 & 842 & 1264 & 127 & 0.43 & $\begin{array}{l}0.8 \\
2\end{array}$ & 46 \\
\hline RCC2 & 295 & 2.21 & 842 & 1264 & 127 & 0.43 & $\begin{array}{l}0.8 \\
4\end{array}$ & 40 \\
\hline
\end{tabular}

\begin{tabular}{|l|l|l|l|l|l|l|l|l|}
\hline RCC3 & 295 & 2.95 & 842 & 1264 & 127 & 0.43 & 0.8 & 32 \\
& & & & & & & 7 & \\
\hline RCC0 & 295 & 0 & 842 & 1264 & 127 & 0.43 & 0.8 & 51 \\
\hline
\end{tabular}

\section{CASTING OF SPECIMENS}

\subsection{Cube Specimens}

Cube Specimens were casted for measuring of compressive strength. For each set of concrete cube specimens we used cube mould sizes of $150 \mathrm{~mm} \times 150 \mathrm{~mm} \times 150 \mathrm{~mm}$, concrete is placed and compacted with modified proctor's rammer. After 24 hours, the specimens are demoulded and kept in water for curing

\subsection{Prism Specimens}

Beam moulds of size 500 x 100x $100 \mathrm{~mm}$ size were used for measuring modulus of rupture of RCC. Concrete is placed in beam moulds and compacted with modified proctor's rammer. They were demoulded and kept for curing.

\subsection{Cylindrical Specimens}

Cylinder moulds of $150 \mathrm{~mm}$ x $300 \mathrm{~mm}$ size were used for measuring split tensile strength.

\section{TESTING AND DISCUSSION OF TEST RESULTS}

\subsection{Compressive Strength}

Cubical Specimens of size $150 \mathrm{~mm}$ x $150 \mathrm{~mm}$ size were tested under compressive loading at 3 days, 7 days and 28 days. The apparatus had a loading capacity of 300 Ton. The Compressive Strength test results for each of the mix proportion are presented in the Table 4.

Table 4. Compressive Strength Test results

\begin{tabular}{|l|l|l|l|l|}
\hline \multirow{2}{*}{$\begin{array}{l}\text { SP } \\
\text { dosage }\end{array}$} & \multirow{2}{*}{$\begin{array}{l}\text { Fine } \\
\text { Aggregate }\end{array}$} & \multicolumn{3}{|c|}{ Compressive Strength $\left(\mathbf{N} / \mathbf{m m}^{\mathbf{2}}\right)$} \\
\cline { 3 - 5 } & & 3 days & 7 days & 28 Days \\
\hline $0.5 \%$ & River Sand & 15.11 & 28.44 & 34.66 \\
\hline $0.75 \%$ & River Sand & 24.44 & 30.22 & 40.44 \\
\hline $1.00 \%$ & River Sand & 28.44 & 36.66 & 42.22 \\
\hline
\end{tabular}

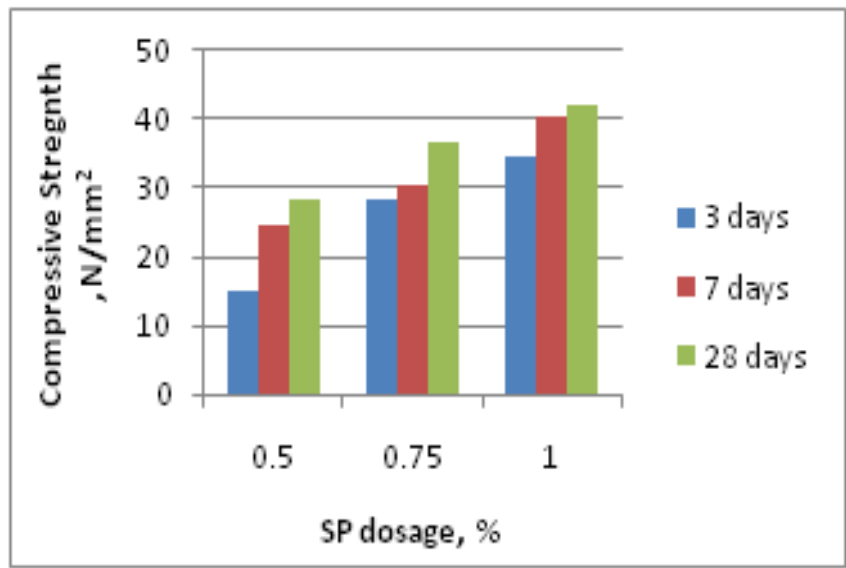

Fig.4 Variation of Compressive Strength with sp dosage 


\subsection{Flexural Strength}

Prism Specimens of size 500x 100mm x 100mm size were tested under flexure center point loading at 3 days, 7 days and 28 days. The UTM apparatus had a loading capacity of 60 Ton. The Flexural Strength test results for each of the mix proportion are presented in the Table 5.

Table 4. Flexural Strength Test results

\begin{tabular}{|l|l|l|l|l|}
\hline \multirow{2}{*}{$\begin{array}{l}\text { SP } \\
\text { dosage }\end{array}$} & \multirow{2}{*}{$\begin{array}{l}\text { Fine } \\
\text { Aggregate }\end{array}$} & \multicolumn{3}{|c|}{ Flexural Strength $\left(\mathbf{N} / \mathbf{m m}^{2}\right)$} \\
\cline { 3 - 5 } & & 3 days & 7 days & 28 Days \\
\hline $0.5 \%$ & River Sand & 4.12 & 4.80 & 6.0 \\
\hline $0.75 \%$ & River Sand & 4.80 & 5.40 & 6.9 \\
\hline $1.00 \%$ & River Sand & 5.20 & 5.60 & 7.4 \\
\hline
\end{tabular}

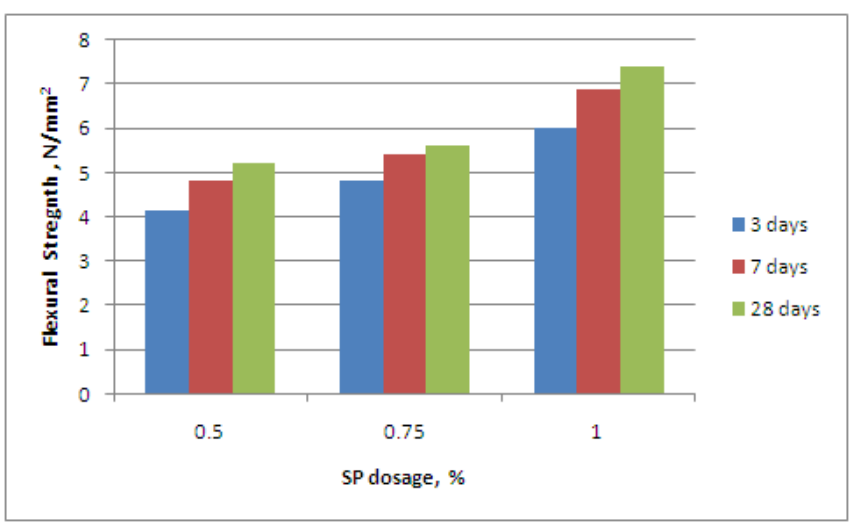

Fig.5 Variation of Flexural Strength with sp dosage

\subsection{Split Tensile Strength}

Cylindrical Specimens of size 150x 300mm size were tested under split tension loading at 3 days, 7 days and 28 days. The CTM apparatus had a loading capacity of 300 Ton. The Split Tensile Strength test results for each of the mix proportion are presented in the Table 6.

Table 6. Split Tensile Strength Test results

\begin{tabular}{|l|l|l|l|l|}
\hline \multirow{2}{*}{$\begin{array}{l}\text { SP } \\
\text { dosage }\end{array}$} & \multirow{2}{*}{$\begin{array}{l}\text { Fine } \\
\text { Aggregate }\end{array}$} & \multicolumn{3}{|l|}{ Split Tensile Strength $\left(\mathbf{N} / \mathbf{m m}^{\mathbf{2}}\right)$} \\
\cline { 3 - 5 } & & 3 days & 7 days & 28 Days \\
\hline $0.5 \%$ & River Sand & 1.55 & 2.12 & 2.82 \\
\hline $0.75 \%$ & River Sand & 1.69 & 2.40 & 3.19 \\
\hline $1.00 \%$ & River Sand & 1.69 & 2.54 & 3.25 \\
\hline
\end{tabular}

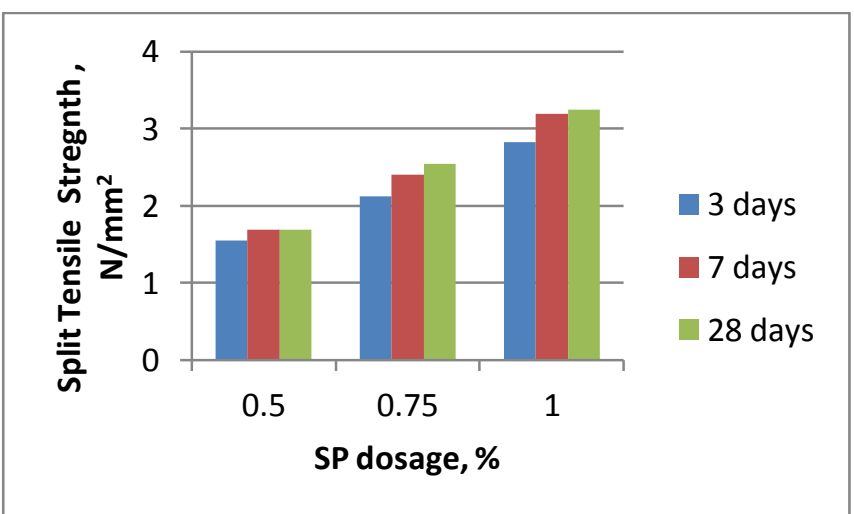

Fig.6 Variation of Split Tensile Strength with sp dosage

\section{CONCLUSION}

1. From the above work it is concluded that RCCP mixes can be proportioned using soil compaction method

2. Flexural Strength increases with increase in cement content. At $14 \%-14.5 \%$ of cement content a flexural strength of $4.5 \mathrm{M} \mathrm{Pa}-5.0 \mathrm{M} \mathrm{Pa}$ was observed which is suitable for rigid pavement construction in India.

3. Cement content per cubic meter is $295 \mathrm{~kg}$, which worked out to be the economical advantage of RCCP over conventional concrete.

4. Workability of RCC was increased with increase in SP dosage

5. Flexural, Compressive and Split tensile strengths were increased at all ages with SP dosages of $0.5 \%, 0.75 \%$ and $1.00 \%$ by weight of Cement respectively.

\section{REFERENCES}

[1]. ACI 325 10R-95,state-of-the-Art report on roller compacted concrete pavements, ACI manual of concrete practice, ACI,USA, 2000:32PP

[2]. ACI Committee 207.5R-99, “ Roller-Compacted Mass Concrete, ", 1999

[3]. ACI 211 3R-02, Guide for Selecting Proportions for NoSlump Concrete, 2002

[4]. Hisham Y Qasrawi, Ibrahim M AsiH.I.AlAbdualWahhab, Proportioning RCCP mixes under hot weather conditions for a specified tensile strength, cement and concrete research, 35(2005) 267-276.

[5]. R Piggot, Roller compacted concrete for heavy duty pavement:past performance , Recent projects and recommended constructed methods, TRR 1062, National Research Council , Washington ,DC,1986,pp7-12

[6]. S.Krishna Rao, P.Sarika, P.Sravana, T.Chandra Sekhara Rao, Evaluation of Properties of roller compacted concrete Pavement, International Journal of Education and Applied Research, ISSN:2348-0033, Vol.4, Issue Spl-2, JAN-JUNE 2014

[7]. S.Krishna Rao, Dr.T.Chandra Sekhara Rao, Dr.P.Sravana, International Journal of Engineering Research and Technology, ISSN: 2278-0181, Vol.2, Issue2, February2013.

[8]. S.Krishna Rao, Dr.T.Chandra Sekhara Rao, Dr. P.Sravana, "Mix Design of Roller Compacted Concrete: An experimental study Using Crushed Stone \& River Sand as Fine Aggregate", National Conference on SCMAT, NIT Warangal, 2013.

[9]. Portland cement Association, (2004). Guide Specification for Construction of Roller-Compacted Concrete Pavements, IS009.01, 8p. Portland cement Association, USA.

\section{BIOGRAPHIES}

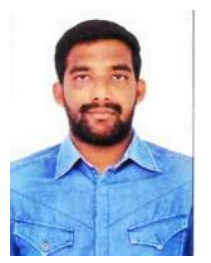

Y.Mohan - He received B.Tech Degree from V.R.Siddhartha Engineering College. Presently he is pursuing M.Tech in V.R.Siddhartha Engineering College, Vijayawada. 
S.Krishna Rao-He Had Received B.Tech Degree from Bapatla Engineering College Bapatla and M.E. from S.G.S. Institute of Technology and Science, Indore. Presently he is pursuing Ph.D from JNTUH, Hyderabad 